Információközvetítés és közösségépítés - multifunkciós könyvtári hálózatok. Szerk. Kiszl Péter, Németh Katalin. Budapest, ELTE BTK

Könyvtár- és Információtudományi Intézet. 2020. 9-30.

\title{
KÖNYVTÁRDIPLOMÁCIA - TUDOMÁNY- ÉS SZAKMAPOLITIKA A NEMZETKÖZI KÖNYVTÁRI-INFORMÁCIÓS SZERVEZETEKBEN
}

\author{
KISZL PÉTER
}

\section{TARTALMI ÖSSZEFOGLALÓ}

A Magyar Könyvtárosok Egyesülete (MKE) 1935-ben történt megalakulása óta végig jelentős, de története során eltérő intenzitású és fókuszú nemzetközi kapcsolatokkal bír, melyek mindenkor hatást gyakorolnak a hazai könyvtárügyre és a könyvtáros szakmai közösségre. A magyar szakemberek közül meghatározó jelentőségü Barátné Hajdu Ágnes könyvtárdiplomáciai tevékenysége, aki az MKE alelnökeként, majd elnökeként, a budapesti és a szegedi felsőfokú könyvtárosképzés emblematikus vezető oktatójaként egyedülálló sikereket ért el nemzetközi szakmai szervezetekben és testületekben. Karrierjének állomásai fontos tanulságokkal szolgálhatnak, különösen a globális információközvetítés és a multifunkciós könyvtári hálózatok korában, és nem utolsósorban példaként állíthatók valamennyi könyvtáros elé.

\section{Kultúrdiplomácia - kultúrpolitika}

A francia 'diplomatie' szó egy komoly és elegánsnak tartott tevékenységre, a nemzetközi kapcsolatok ápolására, a külügyek intézésére utal. Nem véletlen, hogy minden állam önálló minisztériumba (rendszerint a külügyminisztériumába) koncentrálja az ezzel összefüggő, a világpolitikában és világgazdaságban érdekeit képviselő munkáját.

Nem szabad azonban elfeledkezni, hogy a kultúrdiplomácia is szerves része a külföldi országokkal történő kapcsolattartásnak. Hankiss János, a Debreceni Egyetem Francia Tanszék alapító irodalomtörténész professzora, majd az egyetem könyvtárosa 1936-ban megjelent $A$ kultúrdiplomácia alapvetései címü kötetében így fogalmaz: „Kultúrdiplomácia mindig volt, amióta csak emberek szükségét érezték annak, hogy más emberekben a maguk értékének tudatát felkeltsék, s ezzel rájuk befolyást gyakoroljanak." "A szerző - a korszak sajátosságait hordozó müben - a kulturális külpolitika terminus mellett foglal állást a kultúrdiplomáciával szemben. N. Szabó József, a Nyíregyházi Egyetem professzora Magyar kultúra - egyetemes kultúra. Magyarország kultúrdiplomáciai törekvései 1945-1948 címü, az ezredforduló küszöbén kiadott könyvében ${ }^{2}$ hangsúlyozza a kulturális kapcsolatok nélkülözhetetlenségét, mely például a 2 . világháború utáni időszakban is kitörési pontot jelentett a nemzetközi elszigeteltségből.

A kultúrdiplomácia és a tágabb kontextust jelentő kultúrpolitika hazai irodalma föként történeti irányultságú, ${ }^{3}$ a külföldi publikációk ${ }^{4}$ között nagyobb számban for- 
dul elő az aktualitásokat tárgyaló mű. Kurrens kérdéseket középpontba helyezö tudományos fórumként az International Journal of Cultural Policy címü nemzetközi szakfolyóiratra irányítjuk a figyelmet. A szerkesztőség definiálásában a kultúrpolitika "Cultural policy is understood as the promotion or prohibition of cultural practices and values by governments, corporations, other institutions and individuals."

Bevezetőnk végén az 1999-ben az Amerikai Egyesült Államokban alakult, mára Berlinben is székhellyel rendelkező Institute for Cultural Diplomacy $(I C D)^{6}$ kiterjedt - konferenciák szervezését, képzést, közösségépítést stb. magába foglaló - működésének vezérelvét emeljük ki: „Cultural Diplomacy may best be described as a course of actions, which are based on and utilize the exchange of ideas, values, traditions and other aspects of culture or identity, whether to strengthen relationships, enhance socio-cultural cooperation or promote national interests; Cultural diplomacy can be practiced by either the public sector, private sector or civil society."

\section{Az MKE külföldi kapcsolatai}

A könyvtári hálózat Magyarország legnagyobb kulturális intézményrendszere, volumenében kiemelkedik más közgyüjteménytípusok (levéltár és múzeum), valamint a közművelődés hálózata közül. ${ }^{8}$ Kultúraformáló szerepe vitathatatlan, ahogy a külföldi partnerekkel történő szakmai kapcsolattartás nélkülözhetetlensége.

Megszületésétől fogva mindvégig felismerte ennek stratégiai jelentőségét a $\mathrm{Ma}$ gyar Könyvtárosok Egyesülete ${ }^{9}$ is. A Könyvtáros Egyesületek és Szervezetek Nemzetközi Szövetsége (International Federation of Library Associations and Institutions - IFLA, korábbi nevén: International Library and Bibliographical Committee - ILBC) $)^{10} 1927$-es magalakulásán sajnos még nem volt jelen magyar képviselö, ${ }^{11}$ azonban az első, 1929ben Rómában tartott kongresszusán ${ }^{12}$ Pasteiner Iván, a budapesti Egyetemi Könyvtár igazgatója - Klebelsberg Kunó kultuszminiszter jóvoltából - bejelentette a magyar könyvtárszakmai szervezet megalakulásának tervét, egyúttal csatlakozási szándékát a nemzetközi szövetséghez. ${ }^{13}$ A hosszú előkészület után, 1935-ben megszületett MKE (akkori nevén: Magyar Könyvtárosok és Levéltárosok Egyesülete) az idők során az IFLA fontos partnerévé vált, mely kiolvasható az egyesület 2011-ben, a 75. évfordulóra - Bényei Miklós szerkesztésében - megjelent jubileumi kiadványának lapjairól, elsősorban a területi és szakterületi szervezetek történeteiből,${ }^{14}$ ahogy több magyar vonatkozást rögzít az IFLA 1927-2012 közötti időszakot tárgyaló kronológiája is. ${ }^{15}$

Az 1935 óta MKE-tag Vértesy Miklós kétrészes egyesülettörténeti tanulmánya ${ }^{16}$ ugyancsak több ponton utal a kezdetek óta élénk nemzetközi szakmai kapcsolatokra, melyek nemcsak az IFLA, hanem például már a második világháború előtt a Nemzetközi Dokumentációs Szövetség (Fédération Internationale de Documentation - FID, 2002-es megszüntéig: Fédération Internationale d'Information et de Documentation) ${ }^{17}$ tagságával is jártak. Az igazi sikert az 1972-ben Budapesten ren- 
dezett 38. IFLA kongresszus jelentette, ahol 40 ország képviseletében 800 könyvtáros szakember vett részt. ${ }^{18}$ Ezzel összekötve a FID és a Müszaki Egyetemi Könyvtárak Nemzetközi Szövetsége (International Association of Technological University Libraries, ma: International Association of Scientific and Technological University Libraries - IATUL) ${ }^{19}$ ugyancsak a fővárosban tartotta szakmai seregszemléit. ${ }^{20}$

1978-ban létrejött az IFLA Tudományos és Müszaki Könyvtárak Szekciója (Science and Technology Libraries Section), ${ }^{21}$ melynek első titkára, majd 1979-1981 közti elnöke Vajda Erik lett, elnökségi tagjai között tünt fel Papp István, Tombor Tibor és Vályi Gábor. ${ }^{22}$ 1974-ben Papp Istvánt felkérték tagnak az IFLA Journal ${ }^{23}$ szerkesztőbizottságába, majd 1983-ig az elnöki pozíciót is betöltötte, amikor IFLA-Emlékéremmel $(\text { IFLA Medal })^{24}$ tüntették ki. ${ }^{25}$ Papp István rendszeresen tudósította a hazai szaksajtót az IFLA eseményeiről, fontosabb híreiről. ${ }^{26}$

Gombocz Istvánt az IFLA Nemzetközi Kiadványcsere Bizottság'g7 titkárává választották, 1973-ig, haláláig elnökként is regnált, emellett a Magyar UNESCO Bizottság aktív tagjaként dolgozott. Az emlékére alapított ösztöndíjjal számos könyvtáros utazhatott tengerentúli tapasztalatcserére, a Kenti Állami Egyetemre. ${ }^{28}$

Nemzetközileg is sikeres szakmai életutat mondhat magáénak az Idöszaki Kiadványok Adatait Nyilvántartó Nemzetközi Rendszer (International Serials Data System ISDS ${ }^{29}$ párizsi Nemzetközi Irodáját is egykor igazgató és még számos fontos tisztségben (pl. UNESCO, Európai Unió) dolgozó Szilvássy Judit, ${ }^{30}$ akit az IFLA Időszaki Kiadványok Szekció (Section on Serial Publication, ma: Serials and Other Continuing Resources Section - SOCRS) ${ }^{31}$ megbízott az 1996-ban megjelent, időszaki kiadványok kezelésével foglalkozó alapmü² összeállítására. Ugyancsak e szekció Állandó Bizottságának (Standing Committee) tagja volt az 1999-2003 és 2003-2007 közötti periódusban Gazdag Tiborné. ${ }^{33}$

Az MKE kapcsolatai természetesen nemcsak a világszervezetekre korlátozódtak: több együttműködési megállapodás született európai (pl. angol, nyugatnémet), de különösen a környező államok, illetve az egykori szocialista blokkbéli egyesületekkel (pl. jugoszláv, lengyel). A rendszerváltást követő aktivitásra sem lehet panasz. A vasfüggöny lebontása után megannyi külföldi tanulmányútra, konferenciarészvételre, vendégelőadásra és határon túli együttmüködésre került sor. Ezek részletes kifejtésére nem vállalkozunk, az adatok megtalálhatók a már említett jubileumi évkönyvben, ${ }^{34}$ illetve Gerö Gyula könyvtártörténeti kronológiájában. ${ }^{35}$

Örömteli, hogy a felsorolt magyar kollégákon kívül még sokan és sokféle tisztségekbe kerültek, ha nem is az IFLA berkeiben, de más jelentős nemzetközi szakmai szervezetben, testületben, projektben, folyóiratoknál. Tanulmányunk további részében az MKE, ezáltal a magyar könyvtárügy ezredforduló utáni nemzetközi kapcsolatrendszerét egyértelmüen meghatározó és revitalizáló, napjainkban is kulcsfontosságú személyiségének, Barátné Hajdu Ágnesnek, az Eötvös Loránd Tudományegyetem Bölcsészettudományi Kar (ELTE BTK) Könyvtártudományi Tanszék vezetőjének orszá- 
gunkon túlmutató, élénk tudományos-szakmai szerepvállalására és kiterjedt külügyi tevékenységére fókuszálunk.

\section{Barátné Hajdu Ágnes nemzetközi szerepvállalása}

Barátné Hajdu Ágnes nemzetközi szerepvállalásának története 1986-ra nyúlik vissza, amikor a Juhász Gyula Tanárképző Főiskola (JGYTF) Központi Könyvtárának igazgatójaként a szomszédos országok hasonló intézményeivel kötött együttmüködési megállapodásokat. Ezt a törekvését folytatta a szegedi Somogyi-könyvtár igazgatójaként, ahol különösen gyümölcsöző kapcsolatot alakított ki a Szabadkai Városi Könyvtárral.

Az ERASMUS programhoz ${ }^{36}$ történt magyarországi csatlakozás után - oktatói fóállásainak megfelelően - először a Szegedi Tudományegyetem Juhász Gyula Pedagógusképző Kar Könyvtártudományi Tanszékének, majd az Eötvös Loránd Tudományegyetem Könyvtár- és Információtudományi Intézetének ERASMUS kapcsolatait építette ki. Utóbbi intézményben jelenleg húsz partnerrel vált lehetővé az oktatók, hallgatók, valamint a munkatársak ki- és beutazása:

1. Åbo Akademi University, Turku

2. Alexander Technological Educational Institute of Thessaloniki

3. Babeş-Bolyai University, Kolozsvár

4. Hacettepe University, Ankara

5. Ionian University, Korfu

6. Jagiellonian University, Krakkó

7. Johannes Gutenberg University, Mainz

8. Josip Juraj Strossmayer University of Osijek

9. Oslo and Akershus University

10. Sapienza University of Rome

11. Technical University of Cologne

12. University of Borås

13. University Carlos III de Madrid

14. University of Florence

15. University of Latvia, Riga

16. University of León

17. University of Lille

18. University of Porto

19. University of Salamanca

20. West University of Timişoara

Hajdu Ágnes negyed százada dolgozikönkéntesként a könyvtárosok legnagyobb és legtekintélyesebb világszervezetében, mely több mint 140 országból számlálja tagjait. Az IFLA Tudásmenedzsment Szekciójának (Knowledge Management Section) ${ }^{37}$ alapítója, majd titkára, állandó bizottsági tagja, programok szervezőbizottságának 
elnöke. 2013-ban kapott először jelölést - magyarként elsőként és eddig egyetlenként az IFLA alapítása óta - az Igazgatótanácsba (Governing Board), mely a szervezet legmagasabb irányító testülete. Az Igazgatótanács mindenkor tíz tagot számlál az egész világból. Hajdu Ágnest a maximálisan betölthető két terminusra megválasztották: 2015-2017 és 2017-2019 között. ${ }^{38}$ Sipilä Sinikka IFLA elnök (2013-2015) történelmi tettnek minősítette Barátné Hajdu Ágnes Governing Board-tagságát a Magyar Könyvtárosok Egyesülete megalakulásának 80. évfordulójára az ELTE Aula Magnában rendezett ünnepségen (1. ábra). Az IFLA elnöke kiemelte, hogy Barátné Hajdu Ágnes nemcsak első magyarként, hanem a régióból is elsőként került a világ könyvtáros és információs szakembereit tömörítő IFLA vezető testületébe. ${ }^{39}$

Az IFLA jelenlegi magyar tisztségviselője ${ }^{40}$ még Kelemen Ida, az Országgyülés Hivatala Képviselői Információs Szolgálat föosztályvezetője, aki az IFLA Országgyülési Könyvtári és Kutatási Szolgáltatások Szekció (Library and Research Services for Parliaments Section) Állandó Bizottságában második ciklusában (2015-2019 és 2019-2023) dolgozik. ${ }^{41}$

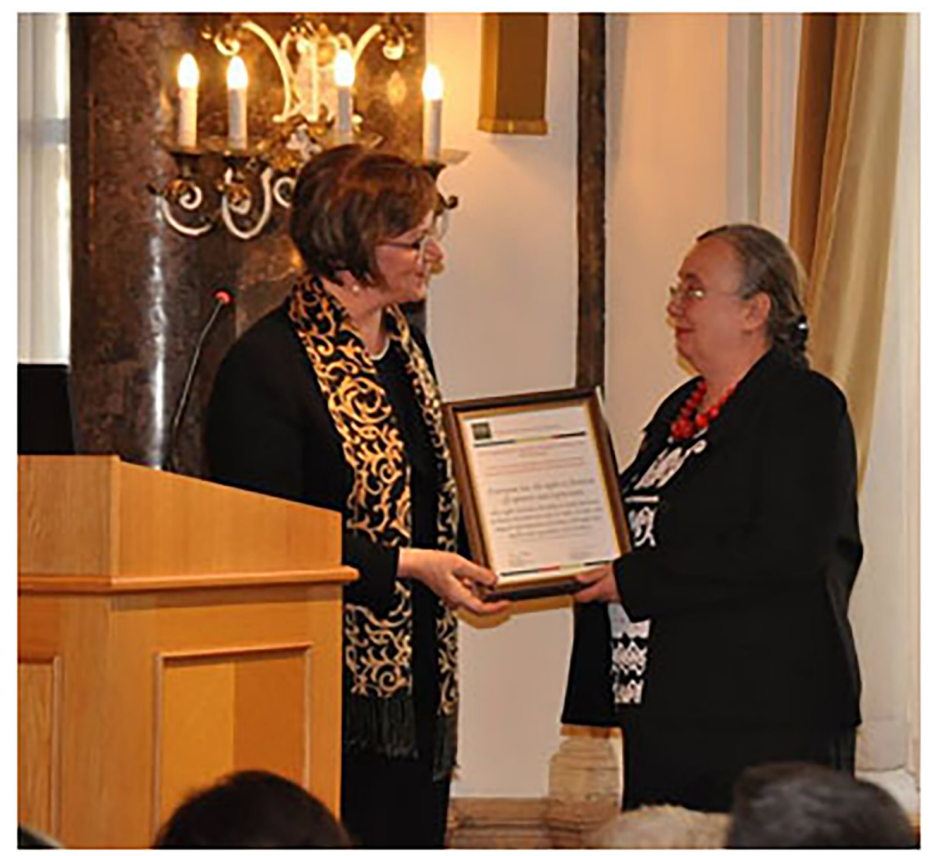

1. ábra

Sipilä Sinikka leköszönő IFLA elnök és Barátné Hajdu Ágnes az MKE 80. jubileumi ünnepségén (2015)

Forrás: http://mke.info.hu/konyvtarvilag/files/2016/01/12310473_399563750240136_3831359 685451276555_n.jpg 


\section{KISZL PÉTER}

\section{Governing Board 2017-2019}

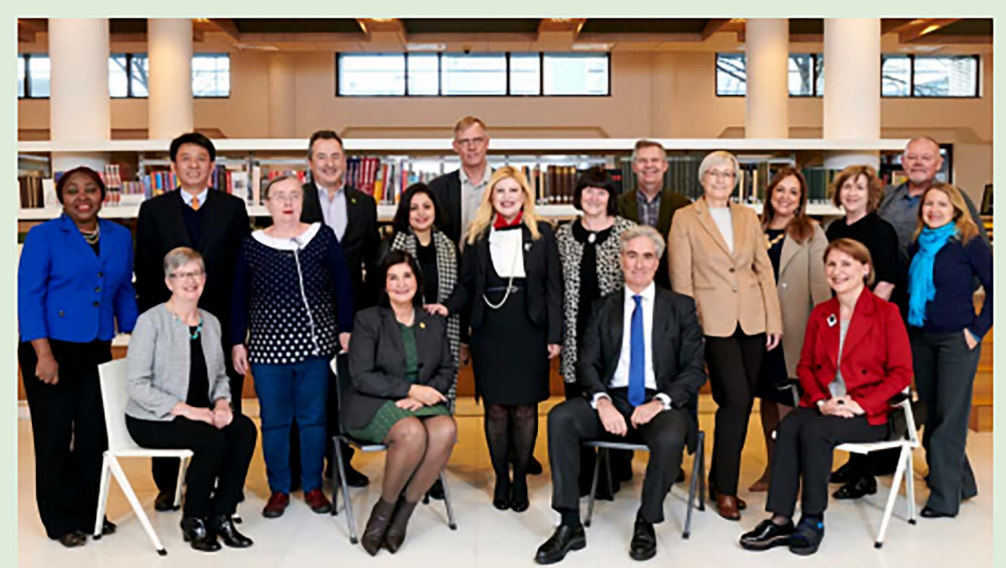

Glòria Pérez-Salmerón Spain (President)

Christine Mackenzie

Australia (President-elect)

Barbara Lison

Germany (Treasurer)
Seated, left to right:

Christine Mackenzie Australia (President-elect) Glòria Pérez-Salmerón Spain (President)

Gerald Leitner
IFLA Secretary General

(member ex-officio)

Barbara Lison

Germany (Treasurer)

Standing, left to right:

Victoria Okojie

Nigeria

Huanwen Cheng

China

Ágnes Hajdu Barát

Hungary

Patrick Losinski

United States of America

Marwa El Sahn

Egypt

Torbjōrn Nilsson

Sweden
Antonia Arahova

Greece (Chair, Division IV)

Ann Okerson

United States of America (Chair,

Division II)

Michael Dowling

United States of America (Chair,

MLAS)

Maja Žumer

Slovenia (Chair, Division III)

Suell Mara Soares Pinto Ferreira

Brazil (Chair, Division V)

Vicki McDonald

Australia (Chair, Division I)

Knud Schulz

Denmark

Ralssa Teodori

Italy (Chair, Professional Committee)

Not pictured:

Viviana Quiñones

France

Victoria Owen

Canada

\section{2. ábra}

Governing Board 2017-2019. IFLA Annual Report 2018

Forrás: https://www.ifla.org/files/assets/hq/annual-reports/2018.pdf 
KÖNYVTÁRDIPLOMÁCIA - TUDOMÁNY- ÉS SZAKMAPOLITIKA A NEMZETKÖZI...

Hajdu Ágnes az IFLA igazgatótanácsi tagságához (2. ábra) kötődően két nagy projektben is oroszlánrészt vállalt:

1. IFLA IAP - International Advocacy Programme (az ENSZ Agenda 2030-hoz és Fenntartható fejlődési céljaihoz kapcsolódó stratégiai program); ${ }^{42}$

2. IFLA Global Vision (7 kontinens 190 országának 31.000 könyvtárosát mozgósító akció, az IFLA jövőbeli cselekvési irányainak meghatározására). ${ }^{43}$

Előbbivel összefüggésben a Magyar Könyvtárosok Egyesülete elnökeként magyar és angol nyelven jó gyakorlatok gyüjteményt adott közre a fenntartható fejlődési célok hazai megjelenéséről nyomtatásban és elektronikusan is hozzáférhetően. ${ }^{44}$ Ennek előzménye, hogy a Könyvtárosok az ENSZ 2030 Agenda és a fenntartható fejlődés megvalósításáért címmel 2017. november 22-én szemináriumot szervezett Budapesten a kapcsolódó könyvtári lehetőségekről és a könyvtári érdekérvényesítés kérdéseiről. ${ }^{45}$

Utóbbi folyományaként moderátori szerepet töltött be Barcelonában 2018. március 20-21. között a Global Vision Discussion workshopon, ahol az IFLA valamennyi tisztségviselője (102 fö) számára szerveztek szemináriumot. 2018. május 14-16. között az európai könyvtáros egyesületek vezetői részvételével tartott regionális IFLA Global Vision Regional Workshop európai rendezvényén vett részt, ahova a Governing Board két tagját hívták meg moderátornak Antonia Arahova és Barátné Hajdu Ágnes személyében. Továbbá jelen lehetett a 2018. június 28-29. között zajló IFLA IAP Global Convening szimpóziumon is.

$\mathrm{Az}$ amerikai Bill and Melinda Gates Alapitvány (Bill and Melinda Gates Foundation) két alkalommal (2010-ben és 2011-ben) is felkérte Tanácsadó Testületének (Advisory Board) tagságára. Az alapítvány Global Libraries programja a könyvtárak és más kulturális intézmények tevékenységét támogatta szerte a világon, melynek keretében a testület 2000 és 2014 között évente egyszer Access To Learning Award (ATLA) díjjal jutalmazta a leginnovatívabb közkönyvtári pályázót. ${ }^{46}$ Az alapítvány szabályai szerint a Tanácsadó Testület tagjai állandóan cserélődtek, és egy szakértő maximum kétszer kaphatott felkérést. Az IFLA számos elnöke is betöltötte ezt a tisztséget.

Barátné Hajdu Ágnes az IFLA mellett több más szakmai és tudományos világszervezet tagja (1. táblázat), a nemzetközi könyvtár- és információtudományi élet és a kutatások aktív résztvevőjeként a világ megannyi államában megfordult pályája során (2. táblázat). Nagy számú nemzetközi konferencia rendezésében vett részt (3. táblázat). Hat IFLA site visit közremüködője, egy alkalommal elnöke (4. táblázat), ami a legjelentősebb éves nemzetközi könyvtár- és információtudományi seregszemlék, az IFLA konferenciák rendezésére pályázó városok helyszíni látogatására, a döntés előkészítésére irányuló megbízást jelenti. 


\section{KISZL PÉTER}

1. táblázat

Barátné Hajdu Ágnes tagsága és tisztségei külföldi tudományos és szakmai testületekben, társaságokban

\begin{tabular}{|c|c|c|}
\hline Szervezet & Tisztség & Idötartam \\
\hline $\begin{array}{l}\text { ISKO (International Society for Knowledge Organization - } \\
\text { Nemzetközi Ismeretszervezési Társaság) } \\
\text { ISKO Scientific Advisory Council }\end{array}$ & $\begin{array}{l}\operatorname{tag} \\
\operatorname{tag}\end{array}$ & 2000 óta \\
\hline $\begin{array}{l}\text { UDC (Universal Decimal Classification) Consortium } \\
\text { Advisory Board } \\
\text { Editorial Team } \\
\text { Executive Committee }\end{array}$ & $\begin{array}{l}\operatorname{tag} \\
\operatorname{tag} \\
\operatorname{tag}\end{array}$ & $\begin{array}{l}2005 \text { óta } \\
2007 \text { óta } \\
2019 \text { óta }\end{array}$ \\
\hline $\begin{array}{l}\text { IFLA (International Federation of Library Associations and } \\
\text { Institutions - Könyvtáros Egyesületek és Szervezetek Nemzetközi } \\
\text { Szövetsége) } \\
\text { Knowledge Management Section Standing Committee }\end{array}$ & $\begin{array}{l}\text { tag } \\
\text { titkár }\end{array}$ & $\begin{array}{l}2005 \text { óta } \\
2006-2009\end{array}$ \\
\hline IFLA Governing Board & $\begin{array}{l}\text { jelölés } \\
\text { tag } \\
\text { tag }\end{array}$ & $\begin{array}{l}2013 \\
2015-2017 \\
2017-2019 \\
\end{array}$ \\
\hline $\begin{array}{l}\text { Bill and Melinda Gates Foundation (Bill és Melinda Gates } \\
\text { Alapítvány) Advisory Board }\end{array}$ & $\begin{array}{l}\text { tag } \\
\text { tag }\end{array}$ & $\begin{array}{l}2010 \\
2011\end{array}$ \\
\hline $\begin{array}{l}\text { ALA (American Library Association - Amerikai Könyvtáros } \\
\text { Egyesület) }\end{array}$ & tag & 2011-2013 \\
\hline
\end{tabular}

2. táblázat

Barátné Hajdu Ágnes nemzetközi tudományos kapcsolatai (válogatás)

\begin{tabular}{|l|l|l|l|}
\hline Ország/város & Intézmény/szakember & Téma & Idő \\
\hline $\begin{array}{l}\text { Chile } \\
\text { Santiago }\end{array}$ & $\begin{array}{l}\text { Ministry of Education - } \\
\text { Constanza Mekis Martinez, } \\
\text { National Coordinator of School } \\
\text { Libraries }\end{array}$ & $\begin{array}{l}\text { könyvtári menedzsment, } \\
\text { közös projekt }\end{array}$ & 1996 óta \\
\hline $\begin{array}{l}\text { Dánia } \\
\text { Aalborg }\end{array}$ & $\begin{array}{l}\text { Aalborg Bibliotekerne - Kirsten } \\
\text { Boelt }\end{array}$ & $\begin{array}{l}\text { IFLA stratégia, pályáza- } \\
\text { tok, workshopok }\end{array}$ & $\begin{array}{l}2015- \\
2017\end{array}$ \\
\hline $\begin{array}{l}\text { Dánia } \\
\text { Koppenhága }\end{array}$ & $\begin{array}{l}\text { The Royal School of Library and } \\
\text { Information Science - Birger } \\
\text { Hjørland }\end{array}$ & $\begin{array}{l}\text { könyvtári osztályozás, } \\
\text { ismeretszervezés, közös } \\
\text { munka az ISKO Tudomá- } \\
\text { nyos Tanácsadó Bizottsá- } \\
\text { gában }\end{array}$ & 2014 óta \\
\hline
\end{tabular}


KÖNYVTÁRDIPLOMÁCIA - TUDOMÁNY- ÉS SZAKMAPOLITIKA A NEMZETKÖZI...

\begin{tabular}{|c|c|c|c|}
\hline $\begin{array}{l}\text { Egyesült } \\
\text { Királyság } \\
\text { London }\end{array}$ & $\begin{array}{l}\text { University College London, } \\
\text { School of Library, Archive and } \\
\text { Information Studies - I. C. } \\
\text { McIlwaine, Aida Slavic, Vanda } \\
\text { Broughton }\end{array}$ & $\begin{array}{l}\text { könyvtári osztályozás, } \\
\text { ismeretszervezés, közös } \\
\text { munka az ISKO Tudomá- } \\
\text { nyos Tanácsadó Bizottsá- } \\
\text { gában és az ETO Konzor- } \\
\text { ciumban }\end{array}$ & 2000 óta \\
\hline $\begin{array}{l}\text { Finnország } \\
\text { Helsinki }\end{array}$ & $\begin{array}{l}\text { Helsinki City Library - Maija } \\
\text { Berndtson, Tuula Havisto }\end{array}$ & $\begin{array}{l}\text { könyvtári menedzsment, } \\
\text { könyvtárépítészet, konfe- } \\
\text { renciák, Bill és Melinda } \\
\text { Gates Alapítvány }\end{array}$ & $\begin{array}{l}1990- \\
2016 \\
2017-\end{array}$ \\
\hline $\begin{array}{l}\text { Finnország } \\
\text { Turku }\end{array}$ & $\begin{array}{l}\text { Åbo Akademi University - } \\
\text { Mariam Ginman, Gunilla Widen- } \\
\text { Wulff }\end{array}$ & $\begin{array}{l}\text { tudásmenedzsment, } \\
\text { Problem based teach- } \\
\text { ing módszerek a } \\
\text { könyvtárosképzésben, } \\
\text { ERASMUS }\end{array}$ & 2000 óta \\
\hline $\begin{array}{l}\text { Franciaország } \\
\text { Lille }\end{array}$ & $\begin{array}{l}\text { University of Lille - Laurence } \\
\text { Favier }\end{array}$ & $\begin{array}{l}\text { könyvtári osztályozás, } \\
\text { ETO, ERASMUS }\end{array}$ & 2015 óta \\
\hline $\begin{array}{l}\text { Hollandia } \\
\text { Hága }\end{array}$ & UDC Consortium - Aida Slavic & $\begin{array}{l}\text { könyvtári osztályozás, } \\
\text { ETO, közös projektek, } \\
\text { közös adatbázisépítés }\end{array}$ & 2005 óta \\
\hline $\begin{array}{l}\text { Hollandia } \\
\text { Hága }\end{array}$ & $\begin{array}{l}\text { IFLA - Glória Peréz Salmerón } \\
\text { elnök }\end{array}$ & $\begin{array}{l}\text { IFLA stratégia, pályáza- } \\
\text { tok, workshop }\end{array}$ & 2005 óta \\
\hline $\begin{array}{l}\text { Horvátország } \\
\text { Eszék }\end{array}$ & $\begin{array}{l}\text { Josip Juraj Strossmayer University } \\
\text { of Osijek - Tatjana Aparac Jelušić }\end{array}$ & $\begin{array}{l}\text { tudásmenedzsment, } \\
\text { BOBCATSSS konferen- } \\
\text { ciák, EUCLID (European } \\
\text { Association for Library } \\
\text { \& Information Education } \\
\text { and Research), ERAS- } \\
\text { MUS }\end{array}$ & 2015 óta \\
\hline $\begin{array}{l}\text { Horvátország } \\
\text { Zagreb }\end{array}$ & $\begin{array}{l}\text { Croatian Library Association - } \\
\text { Tamara Krajna, Marijana Mišetic, } \\
\text { Dunja Holczer }\end{array}$ & $\begin{array}{l}\text { MKE együttműködés, } \\
\text { ENSZ SDGs }\end{array}$ & 2003 óta \\
\hline $\begin{array}{l}\text { India } \\
\text { Shibpur }\end{array}$ & $\begin{array}{l}\text { Bengal Engineering \& Science } \\
\text { University - Susmita Chakraborty }\end{array}$ & $\begin{array}{l}\text { tudásmenedzsment, } \\
\text { közös tanulmánykö- } \\
\text { tet előkészítése (Asian } \\
\text { Chapter, Special Libraries } \\
\text { Association - SLA), több } \\
\text { konferencia program- } \\
\text { szervezése, IFLA Tudás- } \\
\text { menedzsment Szekció }\end{array}$ & 2010 óta \\
\hline
\end{tabular}


KIszl PÉter

\begin{tabular}{|c|c|c|c|}
\hline $\begin{array}{l}\text { India } \\
\text { Visakhapatnam }\end{array}$ & $\begin{array}{l}\text { Andhra University, Department of } \\
\text { Library and Information Science - } \\
\text { Sasikala Chagari }\end{array}$ & $\begin{array}{l}\text { könyvtártudomány, PhD } \\
\text { konzultációk }\end{array}$ & 2010 óta \\
\hline $\begin{array}{l}\text { Lengyelország } \\
\text { Krakkó }\end{array}$ & $\begin{array}{l}\text { Jagiellonian University - Wieslaw } \\
\text { Babik }\end{array}$ & $\begin{array}{l}\text { könyvtári osztályozás, } \\
\text { ISKO, ERASMUS }\end{array}$ & 2000 óta \\
\hline $\begin{array}{l}\text { Lengyelország } \\
\text { Varsó }\end{array}$ & $\begin{array}{l}\text { National Library of Poland - } \\
\text { Elżbieta Stefańczyk, Joanna } \\
\text { Pasztaleniec-Jarzyńska, Magdalena } \\
\text { Gomułka } \\
\end{array}$ & $\begin{array}{l}\text { könyvtári menedzs- } \\
\text { ment, közös projektek, } \\
\text { workshopok, együttmü- } \\
\text { ködési szerződés } \\
\end{array}$ & 2010 óta \\
\hline $\begin{array}{l}\text { Németország } \\
\text { München }\end{array}$ & $\begin{array}{l}\text { University of Applied Sciences for } \\
\text { Public Administration and Legal } \\
\text { Affairs in Bavaria, Department of } \\
\text { Archives and Library Science - } \\
\text { Bernd Lorenz }\end{array}$ & $\begin{array}{l}\text { könyvtári osztályozás, } \\
\text { ETO, nyári egyetemi } \\
\text { együttmüködés }\end{array}$ & $\begin{array}{l}2009- \\
2013\end{array}$ \\
\hline $\begin{array}{l}\text { Németország } \\
\text { Berlin }\end{array}$ & $\begin{array}{l}\text { Humboldt University of Berlin - } \\
\text { Petra Hauke }\end{array}$ & zöld könyvtár & 2005 óta \\
\hline $\begin{array}{l}\text { Norvégia } \\
\text { Oslo }\end{array}$ & $\begin{array}{l}\text { Oslo and Akershus University } \\
\text { College of Applied Sciences - } \\
\text { Ragnar Audunson }\end{array}$ & $\begin{array}{l}\text { könyvtárpolitika, közös- } \\
\text { ségi tér, közös projektek, } \\
\text { workshopok, IFLA, } \\
\text { EUCLID, ERASMUS } \\
\end{array}$ & 1990 óta \\
\hline $\begin{array}{l}\text { Olaszország } \\
\text { Firenze }\end{array}$ & $\begin{array}{l}\text { University of Florence, } \\
\text { Department of Humanities - } \\
\text { Mauro Guerrini }\end{array}$ & $\begin{array}{l}\text { a tartalomfeltárás mai } \\
\text { problémai, Domanovszky } \\
\text { Ákos munkássága } \\
\text { közös projekt, konfe- } \\
\text { rencia, IFLA, EUCLID, } \\
\text { ERASMUS }\end{array}$ & 2005 óta \\
\hline $\begin{array}{l}\text { Olaszország } \\
\text { Parma }\end{array}$ & $\begin{array}{l}\text { University of Parma, Department } \\
\text { of Cultural Heritage and } \\
\text { Performing Arts - Anna Maria } \\
\text { Tammaro }\end{array}$ & $\begin{array}{l}\text { kompetenciák, } \\
\text { könyvtárosképzés, közös } \\
\text { projektek, workshopok, } \\
\text { IFLA, EUCLID }\end{array}$ & 2005 óta \\
\hline $\begin{array}{l}\text { Olaszország } \\
\text { Róma }\end{array}$ & $\begin{array}{l}\text { Sapienza University - Maria } \\
\text { Teresa Biagetti }\end{array}$ & $\begin{array}{l}\text { könyvtári osztályozás, } \\
\text { ERASMUS }\end{array}$ & 1990 óta \\
\hline $\begin{array}{l}\text { Románia } \\
\text { Brassó }\end{array}$ & $\begin{array}{l}\text { Transilvania University of Braşov } \\
\text { - Angela Repanovici }\end{array}$ & $\begin{array}{l}\text { könyvtárosképzés, ERAS- } \\
\text { MUS, pályázatok }\end{array}$ & 2010 óta \\
\hline $\begin{array}{l}\text { Románia } \\
\text { Kolozsvár }\end{array}$ & $\begin{array}{l}\text { Babeş-Bolyai University - Gurka } \\
\text { Balla Ilona }\end{array}$ & $\begin{array}{l}\text { könyvtári osztályozás, } \\
\text { ERASMUS }\end{array}$ & 2003 óta \\
\hline $\begin{array}{l}\text { Románia } \\
\text { Temesvár }\end{array}$ & $\begin{array}{l}\text { Central Library of Politehnica } \\
\text { University of Timisoara - Agneta } \\
\text { Lovasz }\end{array}$ & $\begin{array}{l}\text { könyvtári osztályozás, } \\
\text { kompetenciák, közös } \\
\text { projektek, workshopok, } \\
\text { MKE együttműködés }\end{array}$ & 2010 óta \\
\hline
\end{tabular}


KÖNYVTÁRDIPLOMÁCIA - TUDOMÁNY- ÉS SZAKMAPOLITIKA A NEMZETKÖZI...

\begin{tabular}{|l|l|l|l|}
\hline $\begin{array}{l}\text { Spanyolország } \\
\text { León }\end{array}$ & $\begin{array}{l}\text { University of León, Department of } \\
\text { Library and Information Science - } \\
\text { Blanca Rodrígez Bravo }\end{array}$ & $\begin{array}{l}\text { könyvtári osztályozás, } \\
\text { könyvtárosképzés, konfe- } \\
\text { rencia, ERASMUS }\end{array}$ & 2005 óta \\
\hline $\begin{array}{l}\text { Spanyolország } \\
\text { Madrid }\end{array}$ & $\begin{array}{l}\text { University Carlos III de Mad- } \\
\text { rid, Department of Library } \\
\text { and Information Science - Eva } \\
\text { Mendez Rodrigez, Elías Sanz- } \\
\text { Casado, Rosa San Segundo }\end{array}$ & $\begin{array}{l}\text { könyvtári osztályozás, } \\
\text { kompetenciák, ETO, } \\
\text { könyvtárosképzés, könyv- } \\
\text { tári menedzsment, közös } \\
\text { projektek, workshopok, } \\
\text { ERASMUS }\end{array}$ & 1992 óta \\
\hline $\begin{array}{l}\text { Törökország } \\
\text { Ankara }\end{array}$ & $\begin{array}{l}\text { Hacettepe University, Department } \\
\text { of Information Management - } \\
\text { Serap Kurbanoğlu }\end{array}$ & $\begin{array}{l}\text { információs müvelt- } \\
\text { ség, közös projektek, } \\
\text { EUCLID, ERASMUS }\end{array}$ & 2010 óta \\
\hline
\end{tabular}

3. táblázat

Barátné Hajdu Āgnes hazai nemzetközi és külföldi konferenciák szervezésében történő szerepvállalása

\begin{tabular}{|l|l|l|l|}
\hline Konferencia címe/rendezője & Helyszín & $E$ Ev & $\begin{array}{l}\text { Szervezésben } \\
\text { betöltött szerep }\end{array}$ \\
\hline $\begin{array}{l}\text { InSITE - Informing Science + IT Education } \\
\text { Conferences }\end{array}$ & $\begin{array}{l}\text { Jeruzsálem, } \\
\text { Izrael }\end{array}$ & 2019 & lektorálás \\
\hline $\begin{array}{l}\text { IFLA World Library and Information } \\
\text { Congress, 85th IFLA General Conference } \\
\text { and Assembly/IFLA }\end{array}$ & $\begin{array}{l}\text { Athén, } \\
\text { Görögország }\end{array}$ & 2019 & $\begin{array}{l}\text { szervezőbizottság } \\
\text { tagja, a KM prog- } \\
\text { rambizottság tagja, } \\
\text { lektorálás }\end{array}$ \\
\hline $\begin{array}{l}\text { Kompetenciák és trendek. Nemzetközi kon- } \\
\text { ferencia/MKE }\end{array}$ & $\begin{array}{l}\text { OSZK, } \\
\text { Budapest }\end{array}$ & 2019 & $\begin{array}{l}\text { szervezőbizottság } \\
\text { elnöke, levezetö elnök }\end{array}$ \\
\hline $\begin{array}{l}\text { IFLA World Library and Information } \\
\text { Congress, 84th IFLA General Conference } \\
\text { and Assembly/IFLA }\end{array}$ & $\begin{array}{l}\text { Kuala Lum- } \\
\text { pur, Malajzia }\end{array}$ & 2018 & $\begin{array}{l}\text { szervezöbizottság } \\
\text { tagja, a KM prog- } \\
\text { rambizottság tagja, } \\
\text { lektorálás }\end{array}$ \\
\hline $\begin{array}{l}\text { IFLA Global Vision. 2018 Regional } \\
\text { workshop. Europe/IFLA }\end{array}$ & $\begin{array}{l}\text { Párizs, } \\
\text { Franciaország }\end{array}$ & 2018 & $\begin{array}{l}\text { szervezőbizottság } \\
\text { tagja, table facilitator }\end{array}$ \\
\hline $\begin{array}{l}\text { IFLA strategies and the implementation of } \\
\text { UN 2030 Agenda and SDGs. = Let's work } \\
\text { together on library advocacy! Internatio- } \\
\text { nal workshop for 6 countries/MKE-Polish } \\
\text { Library Association }\end{array}$ & $\begin{array}{l}\text { OSZK, } \\
\text { Budapest }\end{array}$ & 2018 & $\begin{array}{l}\text { szervezőbizottság el- } \\
\text { nöke, levezetö elnök, } \\
\text { moderátor }\end{array}$ \\
\hline $\begin{array}{l}\text { Global Vision discussion. Workshop } \\
\text { Barcelona, } \\
\text { Spanyolor- } \\
\text { szág }\end{array}$ & 2018 & $\begin{array}{l}\text { szervezőbizottság } \\
\text { tagja, table facilitator }\end{array}$ \\
\hline
\end{tabular}




\begin{tabular}{|c|c|c|c|}
\hline $\begin{array}{l}\text { Újra a könyvtárosok szakmai kompetenciá- } \\
\text { iról: kihívások és megoldások. Nemzetközi } \\
\text { konferencia/MKE }\end{array}$ & $\begin{array}{l}\text { OSZK, } \\
\text { Budapest }\end{array}$ & 2018 & $\begin{array}{l}\text { szervezőbizottság } \\
\text { elnöke, lektorálás }\end{array}$ \\
\hline $\begin{array}{l}\text { BOBCATSSS 2018/ ELTE Könyvtár- és } \\
\text { Információtudományi Intézet - University } \\
\text { of Latvia Department of Information and } \\
\text { Library Studies }\end{array}$ & $\begin{array}{l}\text { Riga, } \\
\text { Lettország }\end{array}$ & $\begin{array}{l}2017- \\
2018\end{array}$ & lektorálás \\
\hline $\begin{array}{l}\text { IFLA World Library and Information } \\
\text { Congress, 83th IFLA General Conference } \\
\text { and Assembly/IFLA }\end{array}$ & $\begin{array}{l}\text { Wrocław, } \\
\text { Lengyelor- } \\
\text { szág }\end{array}$ & 2017 & $\begin{array}{l}\text { szervezőbizottság } \\
\text { tagja, a KM program- } \\
\text { bizottság tagja }\end{array}$ \\
\hline $\begin{array}{l}\text { Changing Paradigm of Agricultural } \\
\text { Librarianship/ MKE, IFLA, Magyar Mező- } \\
\text { gazdasági Múzeum és Könyvtár (MMMK) }\end{array}$ & $\begin{array}{l}\text { MMMK, } \\
\text { Budapest }\end{array}$ & 2017 & $\begin{array}{l}\text { szervezőbizottság } \\
\text { elnöke }\end{array}$ \\
\hline IFLA Global Vision Workshop/IFLA & $\begin{array}{l}\text { Athén, } \\
\text { Görögország }\end{array}$ & 2017 & $\begin{array}{l}\text { szervezőbizottság } \\
\text { tagja }\end{array}$ \\
\hline $\begin{array}{l}\text { Information Visualisation in Humanities/ } \\
\text { Nicolaus Copernicus University }\end{array}$ & $\begin{array}{l}\text { Torun, Len- } \\
\text { gyelország }\end{array}$ & 2017 & $\begin{array}{l}\text { programbizottság } \\
\text { tagja }\end{array}$ \\
\hline $\begin{array}{l}\text { Szakmai ismeretek és készségek - átalakuló } \\
\text { hivatás. Nemzetközi konferencia/MKE }\end{array}$ & $\begin{array}{l}\text { OSZK, } \\
\text { Budapest }\end{array}$ & 2017 & $\begin{array}{l}\text { szervezőbizottság } \\
\text { elnöke }\end{array}$ \\
\hline $\begin{array}{l}\text { IFLA World Library and Information } \\
\text { Congress, 82nd IFLA General Conference } \\
\text { and Assembly/IFLA }\end{array}$ & $\begin{array}{l}\text { Columbus, } \\
\text { Ohio, USA }\end{array}$ & 2016 & $\begin{array}{l}\text { szervezőbizottság } \\
\text { tagja, a Committee } \\
\text { on Standards Open } \\
\text { Session programbi- } \\
\text { zottságának tagja }\end{array}$ \\
\hline $\begin{array}{l}\text { Information Management in a Changing } \\
\text { World Conference - IMCW/ Hacettepe Uni- } \\
\text { versity in Ankara, Turkey, Austrian Compu- } \\
\text { ter Society (OCG) in Vienna }\end{array}$ & $\begin{array}{l}\text { Bécs, } \\
\text { Ausztria }\end{array}$ & 2016 & $\begin{array}{l}\text { tudományos prog- } \\
\text { rambizottság tagja, } \\
\text { lektorálás }\end{array}$ \\
\hline $\begin{array}{l}\text { Szakmai ismeretek és készségek - átalakuló } \\
\text { hivatás. A könyvtáros kompetenciák válto- } \\
\text { zása és megjelenése. Nemzetközi konferen- } \\
\text { cia/MKE }\end{array}$ & $\begin{array}{l}\text { OSZK, } \\
\text { Budapest }\end{array}$ & 2016 & $\begin{array}{l}\text { szervezőbizottság } \\
\text { elnöke }\end{array}$ \\
\hline $\begin{array}{l}\text { Jubileumi Konferencia a Magyar Könyvtáro- } \\
\text { sok Egyesülete megalakulásának 80. évfor- } \\
\text { dulója tiszteletére. Nemzetközi konferencia } \\
\text { /MKE }\end{array}$ & $\begin{array}{l}\text { ELTE Állam- } \\
\text { és Jogtudo- } \\
\text { mányi Kar, } \\
\text { Budapest }\end{array}$ & 2015 & $\begin{array}{l}\text { szervezőbizottság } \\
\text { elnöke }\end{array}$ \\
\hline $\begin{array}{l}\text { Knowledge Management Section program - } \\
\text { WLIC: } 81 \text { st IFLA General Conference and } \\
\text { Assembly/IFLA }\end{array}$ & $\begin{array}{l}\text { Fokváros, } \\
\text { Dél-afrikai } \\
\text { Köztársaság }\end{array}$ & 2015 & $\begin{array}{l}\text { szervezőbizottság } \\
\text { tagja }\end{array}$ \\
\hline
\end{tabular}


KÖNYVTÁRDIPLOMÁCIA - TUDOMÁNY- ÉS SZAKMAPOLITIKA A NEMZETKÖZI...

\begin{tabular}{|c|c|c|c|}
\hline $\begin{array}{l}\text { 6th International Symposium on Information } \\
\text { Management in a Changing World - IMCW/ } \\
\text { Hacettepe University - Sun Yat-sen University }\end{array}$ & $\begin{array}{l}\text { Kanton, } \\
\text { Kína }\end{array}$ & 2015 & $\begin{array}{l}\text { tudományos prog- } \\
\text { rambizottság tagja, } \\
\text { lektorálás }\end{array}$ \\
\hline 13th International ISKO Conference & $\begin{array}{l}\text { Krakkó, } \\
\text { Lengyelor- } \\
\text { szág }\end{array}$ & 2014 & $\begin{array}{l}\text { tudományos prog- } \\
\text { rambizottság tagja, } \\
\text { lektorálás }\end{array}$ \\
\hline $\begin{array}{l}\text { 5th International Symposium on } \\
\text { Information Management in a Changing } \\
\text { World - IMCW/Hacettepe University }\end{array}$ & $\begin{array}{l}\text { Antalya, } \\
\text { Törökország }\end{array}$ & 2014 & $\begin{array}{l}\text { tudományos prog- } \\
\text { rambizottság tagja, } \\
\text { lektorálás }\end{array}$ \\
\hline $\begin{array}{l}\text { Knowledge Management Section program - } \\
\text { WLIC: 80th IFLA General Conference and } \\
\text { Assembly/IFLA }\end{array}$ & $\begin{array}{l}\text { Lyon, } \\
\text { Franciaország }\end{array}$ & 2014 & $\begin{array}{l}\text { szervezőbizottság } \\
\text { tagja }\end{array}$ \\
\hline $\begin{array}{l}\text { Knowledge Management Section program - } \\
\text { WLIC: 79th IFLA General Conference and } \\
\text { Assembly/IFLA }\end{array}$ & $\begin{array}{l}\text { Szingapúr, } \\
\text { Szingapúri } \\
\text { Köztársaság }\end{array}$ & 2013 & $\begin{array}{l}\text { szervezőbizottság } \\
\text { elnöke }\end{array}$ \\
\hline $\begin{array}{l}\text { 4th Information Management in a Changing } \\
\text { World Conference - IMCW/ Hacettepe Uni- } \\
\text { versity - Limerick Institute of Technology }\end{array}$ & $\begin{array}{l}\text { Limerick, } \\
\text { Îrország }\end{array}$ & 2013 & $\begin{array}{l}\text { tudományos prog- } \\
\text { rambizottság tagja, } \\
\text { lektorálás }\end{array}$ \\
\hline $\begin{array}{l}\text { Knowledge Management Section program - } \\
\text { WLIC: 78th IFLA General Conference and } \\
\text { Assembly/IFLA }\end{array}$ & $\begin{array}{l}\text { Helsinki, } \\
\text { Finnország }\end{array}$ & 2012 & $\begin{array}{l}\text { szervezőbizottság } \\
\text { elnöke }\end{array}$ \\
\hline $\begin{array}{l}\text { Information Management in a Changing } \\
\text { World Conference - IMCW/ Hacettepe } \\
\text { University }\end{array}$ & $\begin{array}{l}\text { Ankara, } \\
\text { Törökország }\end{array}$ & 2012 & $\begin{array}{l}\text { tudományos prog- } \\
\text { rambizottság tagja, } \\
\text { lektorálás }\end{array}$ \\
\hline $\begin{array}{l}\text { Az MKE vendége az ALA - American } \\
\text { Library Association - elnöke. Nemzetközi } \\
\text { szeminárium /MKE }\end{array}$ & $\begin{array}{l}\text { OSZK, } \\
\text { Budapest }\end{array}$ & 2011 & $\begin{array}{l}\text { szervezőbizottság } \\
\text { elnöke }\end{array}$ \\
\hline $\begin{array}{l}\text { Knowledge Management Section program - } \\
\text { WLIC: } 77 \text { th IFLA General Conference and } \\
\text { Assembly/IFLA }\end{array}$ & $\begin{array}{l}\text { San Juan, } \\
\text { Puerto Rico }\end{array}$ & 2011 & $\begin{array}{l}\text { szervezőbizottság } \\
\text { tagja, lektorálás }\end{array}$ \\
\hline $\begin{array}{l}\text { A tudás - befektetés a jövőbe. } 75 \text { éves a Ma- } \\
\text { gyar Könyvtárosok Egyesülete. Nemzetközi } \\
\text { jubileumi konferencia/MKE }\end{array}$ & $\begin{array}{l}\text { ELTE Állam- } \\
\text { és Jogtudo- } \\
\text { mányi Kar, } \\
\text { Budapest }\end{array}$ & 2010 & $\begin{array}{l}\text { szervezőbizottság } \\
\text { tagja }\end{array}$ \\
\hline $\begin{array}{l}\text { Knowledge Management Section program - } \\
\text { WLIC: 76th IFLA General Conference and } \\
\text { Assembly/IFLA }\end{array}$ & $\begin{array}{l}\text { Göteborg, } \\
\text { Svédország }\end{array}$ & 2010 & $\begin{array}{l}\text { szervezőbizottság } \\
\text { elnöke, lektorálás }\end{array}$ \\
\hline $\begin{array}{l}\text { Information Management in a Changing } \\
\text { World Conference - IMCW/ Hacettepe } \\
\text { University }\end{array}$ & $\begin{array}{l}\text { Ankara, } \\
\text { Törökország }\end{array}$ & 2010 & $\begin{array}{l}\text { tudományos prog- } \\
\text { rambizottság tagja, } \\
\text { lektorálás }\end{array}$ \\
\hline
\end{tabular}


Kiszl Péter

\begin{tabular}{|l|l|l|l|}
\hline $\begin{array}{l}\text { Knowledge Management Section program - } \\
\text { WLIC: 75th IFLA General Conference and } \\
\text { Assembly/IFLA }\end{array}$ & $\begin{array}{l}\text { Milánó, } \\
\text { Olaszország }\end{array}$ & 2009 & $\begin{array}{l}\text { szervezőbizottság } \\
\text { tagja, a szatellit kon- } \\
\text { ferencia elnöke, lek- } \\
\text { torálás }\end{array}$ \\
\hline $\begin{array}{l}\text { Knowledge Management Section program - } \\
\text { WLIC: 74th IFLA General Conference and } \\
\text { Assembly/IFLA }\end{array}$ & $\begin{array}{l}\text { Quebec, } \\
\text { Kanada }\end{array}$ & 2008 & $\begin{array}{l}\text { szervezőbizottság } \\
\text { tagja, lektorálás }\end{array}$ \\
\hline $\begin{array}{l}\text { Knowledge Management Section program - } \\
\text { WLIC: 73rd IFLA General Conference and } \\
\text { Assembly/IFLA }\end{array}$ & $\begin{array}{l}\text { Durban, } \\
\text { Dél-afrikai } \\
\text { Köztársaság }\end{array}$ & 2007 & $\begin{array}{l}\text { szervezőbizottság } \\
\text { tagja, a szatellit kon- } \\
\text { ferencia elnöke, lek- } \\
\text { torálás }\end{array}$ \\
\hline $\begin{array}{l}\text { Knowledge Management Section program - } \\
\text { WLIC: 72nd IFLA General Conference and } \\
\text { Assembly/IFLA }\end{array}$ & $\begin{array}{l}\text { Szöul, } \\
\text { Dél-Korea }\end{array}$ & 2006 & $\begin{array}{l}\text { szervezőbizottság } \\
\text { tagja, lektorálás }\end{array}$ \\
\hline $\begin{array}{l}\text { Knowledge Management Section program - } \\
\text { WLIC: 71st IFLA General Conference and } \\
\text { Assembly/IFLA }\end{array}$ & $\begin{array}{l}\text { Oslo, } \\
\text { Norvégia }\end{array}$ & 2005 & $\begin{array}{l}\text { szervezőbizottság } \\
\text { tagja, lektorálás }\end{array}$ \\
\hline $\begin{array}{l}\text { Knowledge Management Section program - } \\
\text { WLIC: 70th IFLA General Conference and } \\
\text { Assembly/IFLA }\end{array}$ & $\begin{array}{l}\text { Buenos Aires, } \\
\text { Argentína }\end{array}$ & 2004 & $\begin{array}{l}\text { szervezőbizottság } \\
\text { tagja, a szekció meg- } \\
\text { alapítása }\end{array}$ \\
\hline
\end{tabular}

4. táblázat

Barátné Hajdu Ágnes IFLA site visit részvételei

\begin{tabular}{|l|l|l|l|}
\hline $\begin{array}{l}\text { Konferencia címe/rendezöje/tervezett } \\
\text { idöpontja }\end{array}$ & Helyszín & Év & $\begin{array}{l}\text { Látogatóbizottságban } \\
\text { betöltött szerep }\end{array}$ \\
\hline $\begin{array}{l}\text { WLIC: IFLA General Conference and } \\
\text { Assembly/IFLA/2021 }\end{array}$ & $\begin{array}{l}\text { Rotterdam, } \\
\text { Hollandia }\end{array}$ & 2019 & tag \\
\hline $\begin{array}{l}\text { WLIC: IFLA General Conference and } \\
\text { Assembly/IFLA/2021 }\end{array}$ & Brüsszel, Belgium & 2019 & tag \\
\hline $\begin{array}{l}\text { WLIC: IFLA General Conference and } \\
\text { Assembly/IFLA/2021/2020 }\end{array}$ & $\begin{array}{l}\text { Dublin, } \\
\text { Irország }\end{array}$ & 2019 & tag \\
\hline $\begin{array}{l}\text { WLIC: IFLA General Conference and } \\
\text { Assembly/IFLA/2020 }\end{array}$ & $\begin{array}{l}\text { Guadalajara, } \\
\text { Mexikó }\end{array}$ & 2019 & elnök \\
\hline $\begin{array}{l}\text { WLIC: IFLA General Conference and } \\
\text { Assembly/IFLA/2020/2022 }\end{array}$ & $\begin{array}{l}\text { Auckland, } \\
\text { Uj-Zéland }\end{array}$ & 2018 & tag \\
\hline $\begin{array}{l}\text { WLIC: IFLA General Conference and } \\
\text { Assembly/IFLA/2020 }\end{array}$ & Bangkok, Thaiföld & 2018 & tag \\
\hline
\end{tabular}


KÖNYVTÁRDIPLOMÁCIA - TUDOMÁNY- ÉS SZAKMAPOLITIKA A NEMZETKÖZI...

Barátné Hajdu Ágnes nevéhez mintegy 60 nemzetközi konferenciaelőadás is füződik, ${ }^{47}$ emellett külföldi folyóiratok és könyvsorozatok szerkesztöje:

- JLIS.it - Italian Journal of Library and Information Science (Firenzei Egyetem, 2010 óta lektor és a folyóirat tudományos tanácsadó testületének tagja);

- Extension and Correction to the UDC (2005 óta lektor és a folyóirat szerkesztőbizottságának tagja);

- Information Visualisation in Humanities (2017 óta a könyvsorozat szerkesztőbizottsági tagja).

Az IFLA konferenciákon kívül két nemzetközi konferenciasorozat rendszeresen felkért lektora:

1. Informing Science Institute's InSITE Conference, International Board of Reviewers 2011-töl;

2. Information Management in a Changing World Conference - IMCW, Scientific Programme Committee tag 2010-től.

Eddigi külföldi vendégoktatói tevékenysége nemcsak az ERASMUS partneregyetemekre terjedt ki, két példa:

- Free University of Bozen-Bolzano, Olaszország vendégprofesszor: Knowledge Organization in traditional and electronic circumstances;

- The American Studies Research Centre, Hyderabad, India: Információkereső technikák, Ranganathan osztályozási rendszere.

Hajdu Ágnes külföldi egyetemi szakok programjainak akkreditálásában is szerepet vállalt:

- University of Tartu (2008) Information Management (MA)

- Viljandi Culture Academy (2008)

Information Science and Records Management (applied higher education) Librarianship and Information Science (applied higher education)

- Tallinn University (2008)

Information Science (BA)

Information Science (MA)

Information Management (MA)

Records Management (MA)

Information Science (PhD)

- PhD: University Carlos III de Madrid, Department of Library and Information Science; Andhra University, Department of Library and Information Science; Tallinn University. 
Barátné Hajdu Ágnes ars poétikája, hogy a magyarországi könyvtárostársadalommal megismertesse a legújabb nemzetközi könyvtári trendeket, illetve közelebb (hazánkba) hozza a neves szakembereket. Ennek szép példája az MKE égisze alatt szervezett, a szakmai kompetenciákat tárgyaló nemzetközi konferenciasorozat. A 2016 és 2019 között az Országos Széchényi Könyvtárban négy alkalommal lezajlott eseményfolyamra 27 előadó érkezett külföldről, minden alkalommal a határon túli magyarok lakta területekről is:

1. Szakmai ismeretek és készségek - átalakuló hivatás. A könyvtáros kompetenciák változása és megjelenése az uniós gyakorlatban (2016. március 3.) ${ }^{48}$

Anna Maria Tammaro, IFLA Library Theory and Research Section és University of Parma; Simon Edwards, Chartered Institute of Library and Information Professionals (CILIP) Professional Services; Ulrike Lang Education and Training Department, State and University Library, Hamburg Carl von Ossietzky és IFLA Education and Training Section; Jukka Relander, European Bureau of Library Information and Documentation Associations (EBLIDA) és Finnish Library Association; Maria Micle, Agneta Lovasz West University of Timişoara, Politehnica University of Timişoara és Association of Romanian Librarians,

2. Szakmai ismeretek és készségek - átalakuló hivatás (2017. március 1.) ${ }^{49}$ Ragnar Audunson, Oslo University College; Maria Cotera, IFLA Management of Library Associations Section; Rosa San Segundo, Universidad Carlos III de Madrid, Library and Information Science Department; Ulrike Lang, Education and Training Department, State and University Library, Hamburg Carl von Ossietzky és IFLA Education and Training Section; Varga Éva Kárpátaljai Magyar Könyvtárosok Egyesülete; Zágorec-Csuka Judit, Muravidéki Magyar Nemzeti Önkormányzati Közösség.

3. Újra a könyvtárosok szakmai kompetenciáiról: kihívások és megoldások (2018. március 14. $)^{50}$ Petra Hauke, The Environment, Sustainability and Libraries Special Interest Group of IFLA (ENSULIB); Elzbieta Zybert, University of Warsaw; Namtip Wipawin, Sukhothai Thammathirat Open University, Thaiföld; Evviva Weinraub, IFLA Women, Information and Libraries Special Interest Group; Baiba Holma, University of Latvia; Torbjörn Nilsson, Malmö City Library; Lead Bultrini, Operating Systems and Knowledge Management Division of the Regional Environmental Protection Agency (Agenzia Regionale per la Protezione Ambientale - ARPA), Lazio; Egyházi Dóra, Szlovákiai Magyar Könyvtárosok Egyesülete.

4. Kompetenciák és trendek (2019. április 3.) ${ }^{51}$

Tuula Haavisto, Helsinki City Library, Oodi; Giuseppe Vitiello, EBLIDA; Blanca Rodriguez Bravo, University of Leon; Mauro Guerrini, University of Firenze; Serap Kurbanoğlu, University of Ankara; Rabbi Zsolt, Pélmonostori Városi 
KÖNYVTÁRDIPLOMÁCIA - TUDOMÁNY- ÉS SZAKMAPOLITIKA A NEMZETKÖZI...

Könyvtár, Horvátországi Magyarok Központi Könyvtára; Tomasz Gruszkowski, National Library of Poland; Szőcs Endre, Székelyudvarhelyi Városi Könyvtár. Végül nem hallgathatjuk el, hogy Barátné Hajdu Ágnes igazi tanáregyéniség, aki egyetemi kurzusainak tematikáiba mindig beépíti kurrens nemzetközi tapasztalatait, de diákjait folyamatosan mentorálja is. A fiatalok így juthatnak el az MKE vándorgyüléseire, ${ }^{52}$ de akár önkéntesként az IFLA konferenciákra ${ }^{53}$ vagy aktuális, a nemzetközi trendekre reagáló témákkal - Hajdu Ágnes egykori szeretett tanáráról, példaképéről elnevezett - intézeti Fülöp Géza Tudományos Diákkörből az Országos Tudományos Diákköri Konferenciára (OTDK). ${ }^{54}$

\section{A könyvtárdiplomácia mestersége}

Nemzetközi pályafutásának már csak a főbb mozzanatokat felvonultató számbavételével is joggal megállapítható, hogy hazai könyvtárosként és könyvtártudósként Barátné Hajdu Ágnes kivételes nemzetközi ismertséget és elismertséget szerzett. Ugyan élete meghatározó helyszínei - szülővárosa Hódmezővásárhely, otthona Szeged és munkahelye Budapest - és hazaszeretete országunkhoz köti, de az elmúlt évtizedekben az általa megtett milliónyi kilométerrel és persze szorgalmas szakmai munkával a háta mögött (és még, ami ezután következik...) bizton állítható: a könyvtártudomány és a könyvtárosképzés nagykövete. Akire mindannyian büszkék lehetünk.

\section{Irodalom és jegyzetek}

1. HANKISS János: A kultúrdiplomácia alapvetése. = Introduction à la „diplomatie culturelle”. Budapest, Magyar Külügyi Társaság, 1936. 3. p. (Questions d'actualité = Időszerü kérdések; 8.) Forrás: https://dea.lib.unideb.hu/dea/bitstream/handle/2437/105567/ Hankiss_J\%C3\%A1nos_A_kult\%C3\%BArdiplom\%C3\%A1cia_alapvet\%C3\%A9se. pdf?sequence $=1 \&$ isAllowed $=y$ [2019. szeptember 29.]

2. N. SZABÓ József: Magyar kultúra - egyetemes kultúra. Magyarország kultúrdiplomáciai törekvései 1945-1948. Budapest, Akadémiai Kiadó, 1998.

3. Pl. BRUCKNER János: A jozefinista kultúrpolitika és az Egyetemi Könyvtár (17801784). = Magyar Könyvszemle, 72. évf. 2. sz. 1956. 112-137. p. Forrás: http://epa.oszk. hu/00000/00021/00224/pdf/MKSZ_EPA00021_1956_72_02_112-137.pdf [2019. szeptember 29.]; Stratégia és kultúra: kulturális külpolitika az új kihívások tükrében. Éger György, Kiss J. László (szerk.). Budapest, Teleki László Alapítvány, 2004. és DRABANCZ M. Róbert - FÓNAI Mihály: A magyar kultúrpolitika története 1920-1990. Debrecen, Csokonai Kiadó, 2005.

4. Pl. az International Journal of Cultural Policy 2015. évi 4. tematikus, kulturális politikával foglalkozó száma: Forrás: https://www.tandfonline.com/toc/gcul20/21/4?nav=tocList [2019. szeptember 29.] vagy GOFF, Patricia M.: Cultural diplomacy. In: The Oxford Handbook of Modern Diplomacy. Andrew F. Cooper, Jorge Heine and Ramesh 


\section{KISZL PÉTER}

Thakur (szerk.). Oxford University Press, 2013. Forrás: http://www.doi.org/10.1093/ oxfordhb/9780199588862.013.0024 [2019. szeptember 29.] és Cultural Diplomacy in Europe: Between the Domestic and the International. Caterina Carta, Richard Higgott (szerk.). Cham, Palgrave Macmillan, 2019. (The European Union in International Affairs) http://www.doi.org/10.1007/978-3-030-21544-6 [2019. szeptember 29.]

5. Aims and scope. International Journal of Cultural Policy. Forrás: https://www.tandfonline. com/action/journalInformation?show=aimsScope\&journalCode=gcul20 [2019. szeptember 29.]

6. Institute for Cultural Diplomacy (ICD). Forrás: http://www.culturaldiplomacy.org [2019. szeptember 29.]

7. ICD Brochure 2019. Forrás: http://www.culturaldiplomacy.org/pdf/ICD_Brochure_2019. pdf [2019. szeptember 29.]

8. A magyarországi könyvtárak statisztikai adatai. Könyvtári Intézet. Forrás: https://ki.oszk. hu/informacioszolgaltatas/magyarorszagi-konyvtarak-statisztikai-adatai [2019. szeptember 29.] és Kulturális statisztika. KultStat. Kulturális Statisztikai Adatgyüjtő Rendszer: https://kultstat.oszk.hu/\#/home/public [2019. szeptember 29.]

9. Magyar Könyvtárosok Egyesülete. Forrás: https://mke.info.hu [2019. szeptember 29.]

10. International Federation of Library Associations and Institutions. Forrás: https://www.ifla. org [2019. szeptember 29.] Történetéről bővebben: IFLA's History. IFLA. Forrás: https:// www.ifla.org/history [2019. szeptember 29.]

11. 1927 Resolution establishing the International Library and Bibliographic Committee, later IFLA. IFLA. Forrás: https://www.ifla.org/files/assets/hq/history/1927-resolution.pdf [2019. szeptember 29.]

12. 1929 programme of the 1st IFLA Congress. IFLA. Forrás: https://www.ifla.org/files/assets/ hq/history/1929_rome_congress_programme.pdf [2019. szeptember 29.]

13. BÉNYEI Miklós: Az egyesület történelmi múltja. In: A Magyar Könyvtárosok Egyesületének története 1935-2009. Jubileumi kiadvány. Bényei Miklós (szerk.). Budapest, MKE, 2011. 10-11. p.

14. BÉNYEI Miklós (szerk.): i. m.

15. WILHITE, Jeffrey M.: 85 Years IFLA. A History and Chronology of Sessions 1927-2012. Berlin-Boston, De Gruyter Saur, 2012. 46, 64, 160, 170, 212., 216., 349. p. (IFLA Publications; 155.)

16. VÉRTESY Miklós: Könyvtárosegyesületünk fél évszázada (1935-1972). = Könyvtáros, 37. évf. 3. sz. 1987. 166-172. p. és VÉRTESY Miklós: Könyvtárosegyesületünk fél évszázada (1972-1986). = Könyvtáros, 37. évf. 4. sz. 1987. 224-230. p.

17. Fédération internationale d'information et de documentation. Bibliothèque nationale de France. Forrás: https://data.bnf.fr/en/11869418/federation_internationale_d_information_ et_de_documentation [2019. szeptember 29.]

18. A konferenciához kapcsolódik a Könyvtári Figyelő 1972. évi 6. tematikus száma, benne: GOMBOCZ István: Az IFLA 1972. évi, budapesti kongresszusa. = Könyvtári Figyelö, 18. évf. 6. sz. 1972. 575-584. p. Forrás: http://epa.oszk.hu/00100/00143/00210/pdf/ EPA00143_konyvtari_figyelo_1972_06_575-584.pdf [2019. szeptember 29.] A konferencia közönségéröl fotót is közöl: WILHITE, Jeffrey M.: i. m. 212. p. 
19. International Association of Scientific and Technological University Libraries. Forrás: https://www.iatul.org [2019. szeptember 29.]

20. BALÁZS Sándor: A FID 1972-ben Magyarországon. = Könyvtári Figyelö, 18. évf. 6. sz. 1972. 585-590. p. Forrás: http://epa.oszk.hu/00100/00143/00210/pdf/EPA00143_ konyvtari_figyelo_1972_06_585-590.pdf [2019. szeptember 29.] és HÉBERGER Károly: Beszámoló a Budapesti Műszaki Egyetem Központi Könyvtárának 1972. évi tevékenységéről. = Tudományos és Müszaki Tájékoztatás, 20. évf. 4. sz. 1973. 274. p. Forrás: https:// tmt.omikk.bme.hu/tmt/article/view/9657/11199 [2019. szeptember 29.]

21. Science and Technology Libraries Section. IFLA. Forrás: https://www.ifla.org/sci-techlibraries [2019. szeptember 29.]

22. SHAW, Dennis: The formation and evolution of the IFLA Science and Technology libraries Section, 1979-90. = Iatul Quarterly, 4. évf. 4. sz. 1990. 205-214. p. Forrás: https://archive. ifla.org/VII/s7/news/iatul44.pdf [2019. szeptember 29.]

23. IFLA Journal. SAGE. Forrás: https://journals.sagepub.com/home/ifl [2019. szeptember 29.]

24. IFLA Medal. Forrás: https://www.ifla.org/honours-awards/ifla-medal [2019. szeptember 29.]

25. IFLA Emlékérem. Kitüntetett személyek. Az Országos Széchényi Könyvtár története. OSZK. Forrás: http://tortenet.oszk.hu/html/magyar/06jelentos_szemelyek/ifla_emlekerem.htm [2019. szeptember 29.]

26. Pl. PAPP István: Hírek az IFLA életéről. = Könyvtári Figyelő, 33. évf. 1. sz. 1987. 100102. p. Forrás: https://epa.oszk.hu/00100/00143/00289/pdf/EPA00143_konyvtari_ figyelo_1987_1_100-102.pdf [2019. szeptember 29.] és PAPP István: IFLA-hírek. = Tudományos és Müszaki Tájékoztatás, 55. évf. 4. sz. 2008. 197-204. p. Forrás: https://tmt. omikk.bme.hu/tmt/article/view/7322/8325 [2019. szeptember 29.]

27. Committee on the International Exchange of Publications, ma: Acquisition and Collection Development Section. IFLA. Forrás: https://www.ifla.org/acquisition-collectiondevelopment [2019. szeptember 29.] Ld. még: GOMBOCZ István: Az IFLA Nemzetközi Kiadványcsere Bizottságának 40 éves müködése. In: Az Országos Széchényi Könyvtár Évkönyve 1970-1971. Budapest, OSZK, 1973. 89-105. p. Forrás: https://epa.oszk. hu/01400/01464/00010/pdf/089-105.pdf [2019. szeptember 29.]

28. BÁTONYI Viola - KOLTAY Tibor: Mit számít? Gombocz-ösztöndíjasok pályájukról. = Könyv, Könyvtár, Könyvtáros, 3. évf. 9. sz. 1994. 51-58. p. Forrás: http://epa.oszk. hu/01300/01367/00155/pdf/06palyazat.pdf [2019. szeptember 29.]

29. SZILVÁSSY Zoltánné: Az ISDS (International Serials Data System = Időszaki kiadványok adatait nyilvántartó nemzetközi rendszer). = Könyvtári Figyelö, 24. évf. 4. sz. 1978. 349-360. p. Forrás: http://epa.oszk.hu/00100/00143/00238/pdf/EPA00143_konyvtari_ figyelo_1978_04_349-360.pdf [2019. szeptember 29.] és SZILVÁSSY Judith: ISDS: Worldwide Serials Control. = IFLA Journal, 8. évf. 4. sz. 1982. 371-378. p. Forrás: https:// doi.org/10.1177/034003528200800403 [2019. szeptember 29.]

30. Szilvássy Judit életútja: BÉQUET, Gaëlle: Interview with Judith Szilvássy. = Ciência da Informação, 44. vol. 2015. 1. no. 23-28. p. Forrás: http://revista.ibict.br/ciinf/article/ download/1439/1617 [2019. szeptember 29.] 


\section{KISZL PÉTER}

31. Serials and Other Continuing Resources Section. IFLA. Forrás: https://www.ifla.org/ serials-and-continuing-resources [2019. szeptember 29.]

32. SZILVÁSSY Judith: Basic Serial Management Handbook. Revised edition. München [etc.], K. G. Saur Verlag. 1996. (IFLA Publications Series; 77.) Ism.: BERKE Barnabásné: Az időszaki kiadványok kezelésének kézikönyve. = Tudományos és Müszaki Tájékoztatás, 45. évf. 12. sz. 1998. 494-496. p. Forrás: https://tmt.omikk.bme.hu/tmt/article/ view/2643/3667 [2019. szeptember 29.]

33. Newsletter of the IFLA Section on Serial Publication. 4. sz. 2003. 6. p. Forrás: https:// archive.ifla.org/VII/s16/pubs/no43.pdf [2019. szeptember 29.]

34. BÉNYEI Miklós (szerk.): i. m.

35. GERŐ Gyula összeáll.: Magyar könyvtártörténeti kronológia. 1-4. köt. Budapest, OSZK, 2009-2014.

36. Mi az ERASMUS+? Európai Bizottság. Forrás: https://ec.europa.eu/programmes/erasmusplus/about_hu [2019. szeptember 29.]

37. Knowledge Management Section. IFLA. Forrás: https://www.ifla.org/km [2019. szeptember 29.]

38. Statement of Candidacy: Ágnes Hajdu Barát (Hungary). For the position of Governing Board Member 2015-2017. Forrás: https://www.ifla.org/node/9478 és Statement of Candidacy: Ágnes Hajdu Barát (Hungary). For the position of Governing Board Member 2017-2019 2nd term. Forrás: https://www.ifla.org/node/11298 2015-ben 664, 2017-ben 803 szavazatot kapott a jelölt: Results of election of Governing Board 2015-2017. Forrás: https://www.ifla.org/node/9590 és Results of election of IFLA Governing Board 20172019. Forrás: https://www.ifla.org/node/11460 [2019. szeptember 29.]

39. Barátné dr. Hajdu Ágnest, a Magyar Könyvtárosok Egyesülete elnökét, újraválasztották az IFLA Governing Boardjába. Forrás: https://mke.info.hu/blog/2017/06/baratne-hajduagnest-a-magyar-konyvtarosok-egyesulete-elnoket-ujravalasztottak-az-ifla-governingboardjaba [2019. szeptember 29.]

40. Az IFLA mai munkatársai között - nevükből következtetve - két további magyar (rokoni) kapcsolatokkal rendelkező kollégát is találunk: Sophie Felföldit és Louis Takácsot: Headquarters. IFLA. Forrás: https://www.ifla.org/hq [2019. szeptember 29.] és Freelancers. Headquarters. IFLA. Forrás: https://www.ifla.org/hq/freelancers [2019. szeptember 29.] Sophie Felföldi egyúttal a European Bureau of Library Information and Documentation Associations munkatársa is: EBLIDA Secretariat: http://www.eblida. org/about-eblida/secretariat.html

41. Standing Committee. Library and Research Services for Parliaments. IFLA: https://www. ifla.org/standing-committee/03

42. The International Advocacy Programme (IAP). IFLA. Forrás: https://www.ifla.org/ldp/ iap [2019. szeptember 29.] A United Nations (UN) Transforming our world: the 2030 Agenda for Sustainable Development és az IFLA Sustainable Development Goals (SDGs) célkitűzéseiről magyar nyelven bővebben: KISZL Péter: Ki viszi át...? A könyvtárak társadalmi felelösségvállalása a digitális korban. = Tudományos és Műszaki Tájékoztatás, 64. évf. 1. sz. 2017. 1-23. p. Forrás: http://tmt.omikk.bme.hu/tmt/article/view/774 [2019. szeptember 29.] Kapcsolódó egyetemi híradás: Barátné Hajdu Ágnes az ENSZ-ben. 
KÖNYVTÁRDIPLOMÁCIA - TUDOMÁNY- ÉS SZAKMAPOLITIKA A NEMZETKÖZI...

ELTE. Forrás: https://www.elte.hu/content/baratne-hajdu-agnes-az-ensz-ben.t.16912 [2019. szeptember 29.]

43. Our vision, Our future. IFLA Global Vision. IFLA. Forrás: https://www.ifla.org/node/11900 [2019. szeptember 29.]

44. Könyvtárosok az ENSZ 2030 Agenda és a fenntartható fejlődés megvalósításáért. Az MKE válasza az IFLA kezdeményezésére. Válogatás a 2017. november 22-i budapesti konferenciát követően a résztvevők által beküldött jó gyakorlatokból. Budapest, MKE, 2018. Forrás: https://mke.info.hu/wp-content/uploads/2018/03/SDG_sztorik_nyomda_finaljav3.pdf [2019. szeptember 29.] és Librarians for implementing the UN 2030 Agenda and sustainable development goals Response of MKE to the IFLA initiative. A selection of good practices submitted by the participants of the conference held in Budapest on November 22, 2017. Budapest, MKE. 2018. Forrás: https://mke.info.hu/wp-content/ uploads/2018/04/SDG_sztorik_ENG.pdf [2019. szeptember 29.] Elérhető az IFLA honlapjáról is: International Advocacy Programme (IAP) Awareness-raising materials from around the world. IFLA. Forrás: https://www.ifla.org/publications/node/91709 [2019. szeptember 29.]

45. Könyvtárosok az ENSZ 2030 Agenda és a fenntartható fejlődés megvalósításáért. MKE. Forrás: https://mke.info.hu/blog/2017/11/konyvtarosok-az-ensz-2030-agenda-es-a-fenntarthatofejlodes-megvalositasaert [2019. szeptember 29.]

46. Global Libraries. Bill and Melinda Gates Foundation. Forrás: https://www.gatesfoundation. org/what-we-do/global-development/global-libraries [2019. szeptember 29.]

47. Publikálásuktól terjedelmi okokból eltekintünk, az aktualizált lista megtekinthető az ELTE BTK Könyvtár- és Információtudományi Intézetének honlapján, Barátné Hajdu Ágnes oldalán: http://lis.elte.hu/hajdu [2019. szeptember 29.]

48. A könyvtáros kompetenciák változása, megjelenése az uniós továbbképzési gyakorlatban. Szakmai beszámoló. MKE. Forrás: https://mke.info.hu/wp-content/uploads/2013/09/ Szakmai_beszamolo_A-konyvtaros-kompetenciak-valtozasa_20160303.pdf [2019. szeptember 29.]

49. Szakmai ismeretek és készségek - átalakuló hivatás. Szakmai beszámoló. MKE. Forrás: https:// mke.info.hu/wp-content/uploads/2013/09/Szakmai-beszamolo_Szakmai-ismeretek-eskeszsegek-BH\%c3\%81.pdf [2019. szeptember 29.]

50. Szakmai beszámoló az „Ưjra a könyvtárosok szakmai kompetenciáiról: kihívások és megoldások” címü országos szakmai konferenciáról. Hungaricana. Forrás: https://static-cdn. hungaricana.hu/media/uploads/reports/2018/magyar_k\%C3\%B6nyvt\%C3\%A1rosok_ egyes\%C3\%BClete_204108_01384.pdf [2019. szeptember 29.]

51. Szakmai beszámoló a Kompetenciák és trendek című országos szakmai konferenciáról. Hungaricana. Forrás: https://static-cdn.hungaricana.hu/media/uploads/reports/2019/ szakmai_204108_01486.pdf [2019. szeptember 29.]

52. Pl. Intézetünk az MKE vándorgyülésén. ELTE LIS. Forrás: http://elte-lis.blogspot. com/2014/08/intezetunk-az-mke-vandorgyulesen.html? $m=1$ [2019. szeptember 29.] és Értékeink a jövőt formálják - Vándorgyüléseink öröksége. ELTE LIS. Forrás: http://eltelis.blogspot.com/2018/08/ertekeink-jovot-formaljak.html [2019. szeptember 29.] 


\section{KISZL PÉTER}

53. Élménybeszámoló: IFLA WLIC Wrocław 2017. ELTE LIS. Forrás: http://elte-lis.blogspot. com/2017/10/elmenybeszamolo-ifla-wlic-wroclaw-2017.html [2019. szeptember 29.]

54. Legfrissebb OTDK-eredményeink: Hallgatóink szereplése az OTDK-n. ELTE LIS. Forrás: http://elte-lis.blogspot.com/2019/05/hallgatoink-szereplese-az-otdk-n.html [2019. szeptember 29.] és Fülöp Géza Könyvtártudományi Tudományos Diákkör. ELTE LIS. Forrás: http://lis.elte.hu/OKTATAS/otdk.html [2019. szeptember 29.]

Kiszl Péter könyvtáros és közgazdász végzettségű habilitált egyetemi docens, az ELTE BTK Könyvtár- és Információtudományi Intézetének igazgatója, az Információtudományi Tanszék és a Könyvtártudományi Doktori Program vezetője, az informatikus könyvtáros BA és a könyvtártudomány MA szak felelőse. Kutatási területei: információ- és tudásmenedzsment, üzleti információ, könyvtárosok és információs szakemberek vállalkozói kompetenciáának fejlesztése. ORCID: 0000-0003-2992-295X 